\title{
In Search of the Enlightenment: Recent Attempts to Create a Social History of Ideas
}

\section{Citation}

Darnton, Robert. 1971. In search of the Enlightenment: Recent attempts to create a social history of ideas. Journal of Modern History 43(1): 113-132.

\section{Published Version}

http://dx.doi.org/10.1086/240591

\section{Permanent link}

http://nrs.harvard.edu/urn-3:HUL.InstRepos:3403042

\section{Terms of Use}

This article was downloaded from Harvard University's DASH repository, and is made available under the terms and conditions applicable to Other Posted Material, as set forth at http:// nrs.harvard.edu/urn-3:HUL.InstRepos:dash.current.terms-of-use\#LAA

\section{Share Your Story}

The Harvard community has made this article openly available.

Please share how this access benefits you. Submit a story.

\section{Accessibility}


In Search of the Enlightenment: Recent Attempts to

Create a Social History of Ideas

\author{
Robert Darnton \\ Princeton University
}

The history of the Enlightenment has always been a lofty affair-a tendency that will not be regretted by anyone who has scaled its peaks with Cassirer, sucked in delicious lungfuls of pure reason, and surveyed the topography of eighteenth-century thought laid out neatly at his feet. But the time has come for a more down-to-earth look at the Enlightenment, because while intellectual historians have mapped out the view from the top, social historians have been burrowing deep into the substrata of eighteenth-century societies. And, as the distance between the two disciplines increases, the climates of opinion multiply and thicken and the Enlightenment occasionally disappears in clouds of vaporous generalizations. The need to locate it more precisely in a social context has produced some important new work in a genre that is coming to be called the "social history of ideas."

Peter Gay, who has sponsored the term, ${ }^{1}$ has attempted to satisfy the need with the second volume of The Enlightenment: An Interpretation (New York, 1969). A half year after the appearance of Gay's book, another secondvolume work came out in France: Livre et société (Paris, 1970), the sequel to a pioneering collection of essays on sociointellectual history produced by a group at the $\mathrm{VI}^{\mathrm{e}}$ Section of the Ecole Pratique des Hautes Etudes in Paris. These two volume 2's make fascinating reading together, because they show two different historiographical traditions converging on the same problem. Gay descends from Cassirer, the VI" Section group from the "Annales" school and from Daniel Mornet's experiments with quantitative history. Curiously, the two traditions seem to ignore each other. In a bibliography that totals 261 pages in both volumes, and that covers an enormous range of European history, Gay never mentions Livre et société. He makes only a few, irreverent references to Mornet and does not seem to have assimilated much "Annales" history. The second volume of Livre et société (the first appeared a year before Gay's first volume) does not refer either to Gay or Cassirer. In fact, Cassirer's The Philosophy of the Enlightenment was not translated into French until 1966 and has not made much impression on French study of the Enlightenment since its original publication in German in 1932, a year before the appearance of Mornet's Les origines intellectuelles de la Révolution française and fourteen years before Paul Hazard's La pensée européenne au $18^{\circ}$ siècle. So here is an opportunity to compare the methods and results of two attempts, expressing two separate historiographical currents, to solve one of the knottiest problems in early modern history: the problem of situating the Enlightenment within the actualities of eighteenth-century society.

1 Peter Gay, The Party of Humanity: Essays in the French Enlightenment (New York, 1964), p. x. 
Gay came to the social history of ideas through an attempt to redefine the Enlightenment. He wanted his "definition" (as he modestly describes his two large volumes) to incorporate the social dimension of the philosophes' experience into a Cassirer-like interpretation of their ideas. This concern testifies to the ever-expanding influence of social history today, but it does not ultimately determine the character of Gay's book, which can be read as intellectual history of the sort that has flourished in the United States for the last few decades. If read in this way, it offers a delightful tour of the Enlightenment, theme by theme, philosophe by philosophe. Gay cuts his way through clichés and breathes new life into figures that had been embalmed and placed on permanent exhibit in the nineteenth century. His philosophes are not desiccated rationalists, naïve prophets of progress, or narrow-minded village atheists. They are complicated individuals with complicated problems, irrational in their calculations of pleasure and pain, and pessimistic in their dedication to the advancement of civilization. Gay does justice to these complexities, especially in the first two chapters of volume 2, by relating the philosophes' ideas to their experience and by eschewing worn-out labels like "The Age of Reason." His own labeling sometimes creates confusion, as when he describes eighteenth-century empiricism as a "revolt against rationalism." (Cassirer, and even d'Alembert, made the point clearer by contrasting the "esprit de système" of the seventeenth century with the "esprit systématique" of the eighteenth.) But the book makes the philosophes live. Its strength consists in its stress on the complex, human dimension of their philosophy.

Although Gay's Enlightenment will delight and instruct anyone who wants to freshen his sense of the past, it deserves to be read as its author intended: not as just another work on the eighteenth century, but as an attempt to establish a new historical genre. Gay needed to develop a social history of ideas in order to bring together the highly distilled philosophical history of Cassirer and the highly specific findings of social history. ${ }^{2}$ Crossbreeding such different historical species raises enormous problems, because Cassirer dealt with modes of thought, like the rise of "critical" as opposed to "mythopoeic" thinking, while social historians are concerned with a different order of phenomena, like the rise of the bourgeoisie. In order to reconcile such opposed viewpoints, Gay adopts a Hegelian device: he defines the Enlightenment as a "dialectical struggle for autonomy" (The Enlightenment, 1:xi; all references are to this work unless otherwise stated).

The history of history is so strewn with dead dialectics that it might seem rash to create a new one as the conceptual framework for a new kind of history. But Gay's social history of ideas will not hold together without his dialectic, so the dialectic deserves to be examined with care. It goes like this: thesis-"The Appeal to Antiquity" (book 1); antithesis-"The Tension with Christianity" (book 2); synthesis-“"The Pursuit of Modernity" (book 3). Gay explains that he is dealing with the Enlightenment in its narrow sense, the philosophy of the philosophes, not with the broad climate of opinion

2 Ibid. See also Peter Gay, The Enlightenment: An Interpretation (New York, 1966), 1: 427; and esp. Peter Gay, "The Social History of Ideas: Ernst Cassirer and After," in The Critical Spirit: Essays in Honor of Herbert Marcuse, ed. Kurt H. Wolff and Barrington Moore, Jr. (Boston, 1967). 
comprising the "Age of the Enlightenment." He argues persuasively that the philosophes' philosophy can be treated as a coherent historical phenomenon, despite their quarrels and contradictions, because they comprised a coherent unit, a "family"; and their dialectic should be understood as a result of the family's actual experience in the actual environment of eighteenth-century Europe and America. Accordingly, the philosophes responded to the demystifying message of the classics, turned that message against Christian mythology, and then liberated themselves from their liberators by rejecting neoclassicism and embracing modernity. Modernity, autonomy, or "The Science of Freedom" (Gay sticks so many ingenious titles and subtitles to his text that it is difficult to remove his ideas from their packaging) means humane, critical, tolerant, realistic liberalism-a faith worthy of modern modernity, Gay suggests, for he has no pretense of writing value-free history.

This dialectical definition raises the problem of determining what set the Enlightenment apart in time as a distinct phenomenon. If Gay's dialectic cannot be pinned down with precision and supported by rigorous reference to evidence, it may float away like the most ethereal Hegelianism; for no dialectic can be static, even if it is intended only as a "definition." It therefore seems best to follow the unfolding of Gay's Enlightenment stage by stage, pausing to take up themes as they appear-notably in the case of the antireligious, "revolutionary," and psychological aspects of the Enlightenment-and reserving two special themes for the end: the Enlightenment's relation to sociopolitical issues and to the spread of literacy.

Assuming that the Enlightenment originated with an appeal to antiquity, the problem is to show what in antiquity appealed to the incipient Enlightenment rather than to other eras. Gay reveals an affinity between the philosophes and the ancients, but he does not prove that the philosophes read their classics differently than did the "classical" writers of the seventeenth century. Even if Gay's argument could be proven-and to do so would require a multitude of studies in comparative literature as thorough as Jean Seznec's Essciis sur Diderot et l'antiquité and Reuben Brower's Alexander Pope: The Poetry of Allusion - the differences in the response to the ancients would have to be explained, and the explanation might involve elements that are unrelated to Gay's "thesis." Gay's discussion of the Renaissance illustrates this difficulty, because he argues that the classical revival during the Renaissance produced the same dialectic as that of the Enlightenment. Then, in order to avoid entangling dialectics or interpreting the Enlightenment as a rerun of the Renaissance, he is forced to emphasize the elements that separated the two periods - the reawakening of religious controversy and the subsequent spirit of toleration and skepticism, the scientific revolution, and the systematic philosophies of the seventeenth century. But are not these new developments precisely the ones that brought about the Enlightenment? And are they not extraneous to Gay's dialectic? Sensing this danger, Gay tries to fit Montaigne, Grotius, Bayle, Bacon, Descartes, Newton, and Locke into a chapter entitled "Pagan Christianity," one of the hybrid terms like "Epicurean Stoicism" that he seems to coin when his argument is overstrained. An admixture of paganism and Christianity may have colored the ideas of those thinkers as it did in the thought of such pagan-Christians as Aquinas and Augustine, but the real question at issue is: What was fundamental and what accidental in producing the Enlightenment? It will not do to display the pagan-Christian dia- 
lectic at the front door and to smuggle Montaigne, Grotius, Bayle, Bacon, Descartes, Newton, and Locke in the back. Once those men have got a foot inside they will take over, making it impossible to preserve the dialectic even as window dressing.

The Enlightenment's enemies present as many problems as its precursors for Gay's thesis, because, according to François Bluche, the magistrates of the Parlement of Paris had the same favorite authors as Gay's philosophesCicero, Horace, Ovid, and Vergil. ${ }^{3}$ And according to the Livre et société group, the educated but unphilosophic general public shared the same taste for the classics. In order to explain why the philosophes reacted peculiarly to the common stock of their culture, Gay would have been forced back to standard accounts of the Enlightenment's origins, which he seems to avoid. His own account does not deal with the classic studies of Paul Hazard and Philippe Sagnac, which argue that the French Enlightenment grew out of a profound crisis during the last years of Louis XIV's reign; nor does it incorporate the recent work on the "crise de conscience" period by Pierre Goubert and Lionel Rothkrug. Gay barely mentions Fénelon, Saint-Simon, and Boulainvilliers; and he entirely ignores Vauban, La Bruyère, and Boisguillebert.

While Gay has difficulty in getting his thesis off and running, his antithesis almost runs away with him. Here the main theme is the radicalization of the Enlightenment's antireligious character. Gay sees it advancing inexorably from toleration to skepticism, deism, and the full-blooded atheism of Hume and Holbach. The philosophes certainly undermined established churches, but few of them, even in the côterie Holbachique, went over to atheism. ${ }^{4}$ And some intellectual currents flowed in the opposite direction-from the arid atheism of Toland and Woolston in Britain and the godless Temple poets in France to the Great Awakening that spread across Europe from Stockholm, Saint Petersburg, and Bavaria during the prerevolutionary decade. As Auguste Viatte has shown, the Enlightenment went out in a great blaze of illuminism.

How incompatible were Christianity and the Enlightenment, in any case? They were enemies in France, but there philosophy fed on persecution and a tradition of anticlericalism absent in Protestant countries. Perhaps, also, it owed more to Jansenism than Voltaire, in his horror at the convulsionaires, wanted to admit. Such, at least, is a hypothesis dangled temptingly in "The Enlightenment: Free Inquiry and the World of Ideas," an essay by Robert Shackleton in the new volume edited by the late Alfred Cobban. Shackleton detects "a de facto alliance, in many respects surprising, between Jansenism

${ }^{3}$ François Bluche, Les magistrats du Parlement de Paris au XVIII siècle (1715-1771) (Paris, 1960), p. 294.

${ }^{4}$ In his Mémoires de l'abbé Morellet sur le dix-huitième siècle et sur la Révolution ([Paris, 1821], 1: 130), Morellet emphasized, "Il ne faut pas croire que dans cette société [Holbach's group], toute philosophique qu'elle était, . . . ces opinions libres outre mesure fussent celles de tous. Nous étions là bon nombre de théistes, et point honteux, qui nous défendions vigoureusement, mais en aimant toujours des athées de si bonne compagnie." The predominance of deism over atheism in the Enlightenment is stressed in Paul Hazard, La pensée européenne au XVIII ${ }^{e}$ siècle: de Montesquieu à Lessing (Paris, 1946). The forthcoming work of Alan Kors should give the final blow to the myth about the rampant atheism of the côterie Holbachique. 
and the Enlightenment." In contrast to Gay's irresistible "tide of atheism" (2: 144), Shackleton even sees some collaboration between the philosophes and the Catholic church, not so much in France as in Spain, Portugal, and Italy, where Cardinal Passionei and Benedict XIV corresponded philosophically with Montesquieu and Voltaire. This Mediterranean Jansenism sometimes protected philosophes under attack by Jansenists in Paris, and it provided weapons for the philosophic floggings administered to Jesuits throughout the Iberian Peninsula and the Habsburg empire, two areas that Gay almost completely omits from his book. The Jesuits themselves pursued modernity while persecuting philosophes, as a reading of the astute articles on science in the Mémoires de Trévoux would confirm. Josephinism and regalism were both enlightened and Catholic, and the interaction of religion and enlightenment in Protestant countries was even more complicated, as Herbert Dieckmann has warned all intrepid synthesizers." There was more pietism than atheism in the works of Kant, less Voltairian Sturm than spiritualistic Drang in the literary revival of Germany, and very little crushing of l'infâme in Johnson's England. Gay is aware of these nuances. He produces some splendid chapters on Lessing and Burke and does not try to picture Jonathan Edwards as Benjamin Franklin. But his Enlightenment remains that of David Hume, who receives the most splendid chapter of all.

The synthesis suffers from the same birth defects as its dialectical brothers. According to Gay's formula, "modernity" or "autonomy" came into being sometime in the late eighteenth century, when the philosophes felt as free from the classics as they did from the Christians. But this was also the era of neoclassicism, which Hugh Honour has defined recently as "the style of the late eighteenth century, of the culminating, revolutionary phase in that great outburst of human inquiry known as the Enlightenment." 7 If Honour is correct, then Gay's synthesis belongs before his thesis, and his eighteenth century runs backward. If Gay is correct, it is difficult to understand why expressions of classicism like the Palais Bourbon and the Oath of the Horatii appeared at the end of the eighteenth century and why manifestations of modernity like the scientific revolution ${ }^{8}$ and the dispute between the ancients and the moderns (which Gay does not mention) occurred at the end of the seventeenth.

But Gay's synthesis suffers less from misplaced modernity than from a tendency to exaggerate the Enlightenment's radicalism. For just as stage two of the dialectic leads to atheism, stage three produces revolution-and reopens the whole question of the connection between Enlightenment and revolution in the eighteenth century. Gay finds the connection fundamental, because

"Alfred Cobban, The Eighteenth Century: Europe in the Age of the Enlightenment (London, 1969), p. 278 (see also Robert Shackleton, "Jansenism and the Enlightenment," Studies on Voltaire and the Eighteenth Century 57 [1967]: 138797).

" Herbert Dieckmann, "Themes and Structure of the Enlightenment," Essays in Comparative Literature (Saint Louis, 1961), pp. 67-71.

‘ Hugh Honour, Neo-classicism (Harmondsworth, England, 1968), p. 13.

${ }^{8}$ In The Edge of Objectivity: An Essay in the History of Scientific Ideas (Princeton, N.J., 1960), Charles C. Gillispie sees a tendency in the scientific thought of the Enlightenment to move away from the strictly scientific toward the romantic, away from Newton toward Diderot and Goethe. 


\section{Robert Darnton}

he sets 1688 and 1789 as chronological boundaries for his book. But he hardly refers to the revolutions of England and France and concentrates instead on the American Revolution-the "Finale" to the dialectic, yet a strangely unrevolutionary affair. Gay does not even mention the Declaration of Independence, which is usually interpreted as the culmination of radical Enlightenment in America. But he goes into a detailed discussion of The Federalist Papers, where he finds the omnipresent "dialectical movement away from Christianity to modernity" (2:563). This unorthodox emphasis creates some confusion, because the most recent work by Bernard Bailyn and Alan Heimert makes it more difficult than ever to imagine the Founding Fathers trading impieties with Hume and Holbach. But Gay's approach permits him to scuttle natural law, which he views as a vestigial metaphysics left over from the seventeenth century and progressively eliminated in the eighteenth. Of course he does not deny that the American revolutionaries, like Montesquieu, Voltaire, Diderot, and Rousseau, often invoked the laws of nature. But he interprets Hume's "revolutionary" (2: 455) attack on natural law as more fundamental to the Enlightenment than Diderot's "revolutionary" (2: 457) defense of it. The confusion comes because almost everything the philosophes did seems to have been revolutionary. Their emphasis on man's natural goodness was "subversive, in fact revolutionary" (2:398), and "revolutionary" was their "rehabilitation of the passions" (2: 192). Their "revolutionary ideology" (1:27) extended far and wide-to a "revolution" (2: 369 ) in historiography and in the theater (Miss Sara Sampson, "a revolutionary drama" [2: 264]), not to mention the "utterly subversive manner" (2: 390) in which they attacked religion. In art, Reynolds's career was "revolutionary in its implications" (2: 234), although as aestheticians Diderot and Lessing were "revolutionaries who never lost their respect for tradition" (2: 250 ). The alarmed reader may be reassured to learn that the philosophes' aversion to the Gothic was "no mark of radicalism" if not downright "reactionary" (2: 217), and that "as a group, the philosophes were a solid, respectable clan of revolutionaries" (1:9). But then he discovers that unlike the classicists of the seventeenth century, who had "concealed their radicalism" (1: 282), the philosophes turned classicism into "an instrument of subversion" (1:264); and their penchant for ancient Greece "remained subversive" (1:75) while "the Enlightenment itself was moving toward overt and bellicose radicalism" (1:200). Gay's Enlightenment is such an explosive affair that one wonders how the Old Regime ever got as far as 1789. The philosophes had the place wired, mined, and booby trapped.

But Gay's narrative does not reach 1789 either: it stops just after the American Revolution-rather anticlimatically for the reader watching the pressure rise toward the big bang. Nonetheless, The Federalist makes a good if somewhat unrevolutionary point to call a halt on all the radicalizing and undermining, because not only was the Enlightenment's influence on the French Revolution problematical, but Gay had argued in an earlier article that it was relatively unimportant. ${ }^{9} \mathrm{He}$ had to dispose of his Humean, Holbachean explosives somewhere; so he dumped them on the United States. An easier solution, however, would have been to delete "revolutionary" from its myriad appearances in the text and to admit that the Enlightenment was

\footnotetext{
9 Peter Gay, "Rhetoric and Politics in the French Revolution," reprinted in The Party of Humanity.
} 
a pretty mild affair after all. By 1778 , when all of Paris was salaaming before Voltaire, the last generation of philosophes had become pensioned, petted, and completely integrated in high society. Ten years later men like Morellet and Dupont labored valiantly to prevent the collapse of the Old Regime, as was perfectly natural, for the High Enlightenment was one of its most important potential props. Quesnay, Turgot, and even Voltaire offered a program of liberal reform, a possibility of perpetuating the social order by blunting its conflicts. The idea of subverting society, if it ever occurred to them, would have struck them as monstrous. Not only did they believe in the basic structure of the Old Regime, they thought that it ought to remain hierarchical. As d'Alembert explained: "Is a great effort of philosophy necessary to understand that in society, and especially in a large state, it is indispensable to have rank defined by clear distinctions, that if virtue and talent alone have a claim to our true homage, the superiority of birth and eminence commands our deference and our respect?" 1 " With exceptions like Rousseau, the philosophes were elitists. They enlightened through noblesse oblige in company with noblemen, and of ten with a patronizing attitude toward the bourgeois as well as the common people. In the article "Goût" of his Dictionnaire philosophique. Voltaire observed, "Taste is thus like philosophy; it belongs to a very small number of privileged souls, ... It is unknown in bourgeois families, where one is continually occupied with the care of one's fortune." It has been argued recently that, far from rising with the middle class, liberalism descended from a long line of aristocrats, and so did the Enlightenment.11 Except for men like Condorcet, the last of the philosophes fit in perfectly with the Sèvres porcelain and chinoiserie of the salons; the High Enlightenment served as frosting for France's thin and crumbling upper crust.

If there was any "radicalism" among the abbés and petits marquis of the synthetic Enlightenment, it was their faith in natural law, the very weapon that Gay excludes from his overstocked arsenal of revolutionary philosophy. The abbé Raynal, who lived to bewail the advent of the Revolution, polemicized against slavery because he considered it contrary to the law of natureand this was not innocuous humanitarianism, because powerful interests fed on slavery, as the Amis des noirs were to learn when they tangled with the Club Massaic during the Revolution. The philosophes justified many other items in their "program," as Gay calls it in his account of their reform campaigns, by reference to what they considered as eternal, immutable values. Gay interprets these references as rhetoric. Like Alfred Cobban, ${ }^{12}$ he emphasizes the strain of utilitarianism in the writings of Holbach, Beccaria, and Bentham and treats Hume's attack on normative reasoning as the turning point in eighteenth-century thought. But what Hume killed with logic lived on

10 D'Alembert, Histoire des membres de l'Académie française morts depuis 1700 jusqu'en 1771 (Paris, 1787), 1: xxxii.

${ }^{11}$ For the Marxist view of a bourgeois Enlightenment, see Lucien Goldmann, "La pensée des 'Lumières,'" Annales: économies, sociétés, civilisations 22 (1967): 752-70. On aristocratic liberalism, see Denis Richet, "Autour des origines idéologiques lointaines de la Révolution française: élites et despotisme," Annales: économies, sociétés, civilisations 24 (1969): 1-23. Jacques Proust, Diderot et l'Encyclopédie (Paris, 1962), contains a sophisticated version of the old issue of the Enlightenment's character as "revolutionary" ideology.

${ }^{12}$ Alfred Cobban, In Search of Humanity: The Role of the Enlightenment in Modern History (New York, 1960), p. 3. 
in the hearts and minds of most philosophes; and Hume, despite Gay's ingenious revisionist interpretation of him, remained a very Tory revolutionary. Why not admit that natural law, codified in influential textbooks like Burlamaqui's Principes du droit naturel, survived throughout the Enlightenment in contradiction to strict empiricism, utilitarianism, and Hume's lethal surgêry? Philosophy thrives on contradictions. In fact there was a built-in contradiction between the descriptive and prescriptive aspects of natural law itself. The philosophes were forever attempting to bring the physical and moral worlds together and to seek spiritual uplift in the Spacious Firmament on High. This tension between the normative and the material is what gave the Enlightenment life. It is fully appreciated in classical studies like Cassirer's The Philosophy of the Enlightenment, Hazard's European Thought in the Eighteenth Century, and-for all Gay's efforts to expunge it-Becker's The Heavenly City of the Eighteenth Century Philosophers.

The final dimension of Gay's dialectic is psychological. It, too, includes a revolution: the emergence of a new personality type-autonomous, demystified, modern man. Psychological modernity, Gay argues, came about through a collective identity crisis among the philosophes. To be sure, an identity crisis on top of a dialectic makes for problems, but Gay does not shrink from an explicitly Eriksonian attack on them. His bibliography contains three generous pages of acknowledgment of works on psychoanalysis and sex that he found helpful, beginning with Erikson-or rather beginning with the beginning: "In my view of sexuality, both its meaning and its history, I have been guided by Freud" (2: 628). It may be that Erikson is feeling overacknowledged these days ( he has been heard to mutter unhappily about learning of an identity crisis in men's wear), but Gay does not use the magic formula frivolously. He argues that the struggle against Christianity produced an identity crisis in the entire family of philosophes and that they were able to resolve it because "it was precisely the growth of the superego in Western culture that made greater sexual freedom possible" (2: 204-5). Thus the dialectic of ancients, Christians, and philosophes apparently corresponded in some way to a three-cornered fight between the id, ego, and superego; and "the Enlightenment is the great rebellion of the ego against irrational authority" (1: 462). This interpretation, however, raises problems for the faithful Eriksonian reader who had been assured by the master that "the Renaissance is the ego revolution par excellence." 13 The problems are compounded by Gay's assertion that "the sexual ideal of the Enlightenment may be said to have been the genital personality" (2:628). Did some subdialectic synthesize orality and anality into genitality? If the philosophes reached such advanced modernity in the eighteenth century, where is "Western culture" today? Polymorphous perversion presumably.

Would it not be easier to give up the subdialectics, reversed antitheses, and entangled syntheses and to admit that the only dialectic in history is historiographical: the dialectic between those who get it right and those who get it written? In this case, alas, the written version is wrong: the Enlightenment was not a dialectical struggle for autonomy.

If one abandons Gay's dialectic, what is left of his social history of ideas? Its feasibility can best be measured by considering Gay's treatment of two final problems: the relation of the Enlightenment to sociopolitical issues and

1:3 Erik H. Erikson, Young Man Luther: A Study in Psychoanalysis and History, 5th ed. (New York, 1962), p. 193. 
to the spread of literacy. Both will be discussed in the context of French history, so that Gay's interpretation can be compared with the findings in Livre et société, a book that belongs to the mainstream of advanced French historiography. The advance has occurred most spectacularly in the study of the Old Regime's social structure and has already reached the textbook stage. The uninitiate therefore need not read every word in the overwhelming tomes of Pierre Goubert, Emmanuel Le Roy Ladurie, Pierre de Saint-Jacob, Roger Dion, René Baehrel, Abel Poitrineau, Paul Bois, François Bluche, and Jean Meyer. They can consult the brief and brilliant popularizations written by Pierre Goubert and Robert Mandrou, ${ }^{14}$ and there they will see that Gay is wrong to reduce the main sociopolitical issues of the eighteenth century to a dualism, pitting the thèse nobiliaire (the reactionary cause championed by the parlements and Montesquieu) against the thèse royale (the progressive cause of royal reformers and Voltaire). The Old Regime was too complicated to be classified so simply, and Voltaire's propaganda was too simplistic to be "good history always and good politics for decades" (2: 483). Contrary to what Gay maintains, the privileged orders paid important sums in taxation, and privilege was not consonant with "order" in any case: it ate through all levels of society, down to the very peasantry. ${ }^{15}$ In defending privilege, the parlements did not so much defend the nobility as protect a complex combination of vested interests typical of traditional societies. Their defense had a wide enough appeal to make their "liberal" rhetoric something more than hypocritical. By the end of the century, they were not the closed, caste-ridden bodies Gay describes. ${ }^{16}$ In fact, contrary to what Gay suggests, Turgot favored their recall in 1774, and Montesquieu's sympathy for them did not amount to a reactionary ideology. Voltaire was a sincere reformer but no great enemy of privilege: he was an annobli, courtier, grand seigneur, and proud possessor of a coat of arms with a fake marquis's crown.

The attack on privilege came less from Ferney than from such unphilosophic quarters as the chancellery and the Contrôle général. Consider the opinion of Charles François Lebrun, who epitomizes a tradition of bureaucratic reform that shaped policy during Maupeou's attack on the parlements: "I did not want to enlist with the philosophes ... I would have preferred to see them devote their energies to a field other than the one they had chosen [i.e., the campaign against the church?]. It seemed to me that the government could make them into useful auxiliaries in the fields of administration and internal politics, could direct their attacks against the barriers which separated province from province, against privileges which placed uneven burdens on the people, against numberless contradictory customary laws, against the diversity of legal systems, against courts which were distant and inaccessible to people bringing suit, against usurped jurisdictions, against that swarm of

14 Pierre Goubert, L'Ancien Régime (Paris, 1969); Robert Mandrou, La France auX XVII' et XVIII' siècles (Paris, 1967).

15 See Goubert, chap. 7; and C. B. A. Behrens, "Nobles, Privileges and Taxes in France at the End of the Ancien Régime," Economic History Review. $2 \mathrm{~d}$ ser.. no. 3 (1963).

16 The complex question of the sociopolitical characier of the parlements has not yet been settled, despite the important theses of François Bluche and Jean Meyer. But the work of Jean Egret has at least dented the standard interpretation of a late eighteenth-century "révolte nobiliaire" (see Egret, "L'aristocratie parlementaire française à la fin de l'Ancien Régime," Re'uc historique' 208 [1952]: 1-14, and La pré-Révolution française [1787-I788] [Paris, 1962]). 
guilds which hindered industry and stopped its progress. In every part of France there were reforms to carry out, people to be enlightened." 17 How much did the reform movement owe to the Enlightenment? Far more, no doubt, than Lebrun acknowledged, but far less than is maintained by most intellectual historians. Administrative history, rather than philosophic theory, might be the place to look for the real thrust behind reformism. Many of the reforms decreed by the Revolution were drafted in the baroque bureaucracy of Louis XIV, as is illustrated in The Single Duty Project by J. F. Bosher, an excellent, unintended example of the social history of ideas. The Old Regime left enough of its red tape behind. Why not go to the archives and get wrapped up in it, instead of reading Voltaire, if one wants to learn how ideas and politics tangled in the eighteenth century? What is true of France applies even more to the rest of Europe. where "enlightened absolutism," as Gay astutely characterizes it, had little relation to the Enlightenment. Most sovereigns reformed in order to maximize power. They reformed with cameralists, not philosophes, drawing on a tradition of bureaucratic rationalizing that went back to the seventeenth, and sometimes the sixteenth, century.

The problems of measuring literacy and reading habits, which have attracted the heaviest research by the Livre et société group, receive somewhat summary treatment by Gay: "In France (to judge from signatures on marriage certificates) the percentage of literate adults rose from about four in ten in 1680 to more than seven in ten a century later" (2: 58). Where Gay got this information is difficult to say, because his book is as short on footnotes as it is long on bibliography. The only historical study of literacy that covers the entire country (the survey directed by Louis Maggiolo in the 1870s) estimates that 21 percent of all French adults could sign marriage certificates in 1686-90, 37 percent in 1786-90, and 72 percent in 1871-75.18

Important consequences result from this apparent confusion of the eighteenth and the nineteenth centuries, because, as Gay says, "The first precondition for a flourishing republic of letters was a wide reading public" (2: 58 ). Believing that literacy soared to 70 percent, he concludes that the philosophes acquired a "new audience" (2: 61), increased prosperity, improved status, and relative freedom from patronage. These conditions not only made the Enlightenment possible but transformed it into a revolutionary force, for Gay never drops the theme of radicalization: "[T]he growing radicalism and increasing freedom of the Enlightenment reflected and produced irreversible, if often subterranean, changes in Western politics, economy, and society. As democrats and atheists took the lead in the family of philosophes, radicals rebelled against constituted authority all over the Western world" (2: 83). This statement comes closer to describing France at the time of the Commune than the France of Voltaire.

Voltaire's France creates enormous problems for the social history of ideas, because the mental world of its inhabitants did not extend very far beyond

17 Lebrun's autobiography, as translated in the anthology of readings edited by John Rothney, The Brittany Affair and the Crisis of the Ancien Régime (New York, 1969 ), p. 243.

$1 \times$ Michel Fleury and Pierre Valmary, "Les progrès de l'instruction élémentaire de Louis XIV à Napoléon III," Population, no. 1 (1957), pp. 71-92. Gay also associates the philosophes with a "linguistic revolution" (2: 60): the shift from Latin to French as the dominant language in which books were published in France. Here his source seems to be David Pottinger, The French Book Trade in the Ancien Régime, 1500-1791 (Cambridge, Mass., 1958). Pottinger, however, 
the boundaries of their social world-beyond the guild, the parish assembly, the regional units of administrative, legal, commercial, and religious institutions; beyond local ways of weighing, measuring, and paying for commodities; and beyond provincial techniques of raising children, dressing, and talking. Most Frenchmen probably did not speak French during Voltaire's childhood. By the time of his death (1778), improved roadways and demographic and economic expansion had brought the country together. But France did not cohere as a nation until after the Revolutionary and Napoleonic periods. To understand how the Enlightenment "took" in such a fragmented society is no easier than to measure its influence on a European scale. Perhaps it never penetrated far below the elite in any area of eighteenth-century Europe.

It is the elite that interests Gay, so he should not be expected to produce a parish-by-parish sociological analysis. The elite shared a common, cosmopolitan culture. Nevertheless, to be a philosophe in Poland was a different experience than to be a philosophe in England. Gay tries to explain the differences by relating them to forces outside the philosophic "family," and this attempt makes him stumble on the complexities of social history. To take the example of literacy again, Gay's interpretation might be rescued by arguing that literacy is only important as a precondition for the growth of a reading public large enough to support a population of writers living entirely from their pens. Thus the crucial factor is that the total number of French readers increased, owing to population growth, although the incidence of literacy remained below the level of "modern" societies. Furthermore, adult male literacy went up significantly (from 29 percent in 1686-90 to 47 percent in 1786-90, using signatures of marriage certificates as an index), and certain areas, particularly in the northeast, reached levels of 80 percent. In fact, a sort of literacy barrier or Maggiolo line ran from Mont Saint-Michel to Besançon or Geneva, separating the north, where literacy was always above 25 percent, from the south, where the rate was usually under 25 percent. ${ }^{19}$ But given this limited, regional growth of the reading public, another question arises: Did the new readers create a new literary market, freeing the philosophes from patronage and thereby radicalizing the Enlightenment? If Diderot's Lettre sur le commerce de librairie, Malesherbes's Mémoires sur la librairie, and the royal edicts on the book trade are to be believed, the answer to that question is no. And if the pension lists in the Archives Nationales indicate trends in patronage, the state subsidized writers in the traditional manner under Louis XVI, and may have subsidized more of them than in the days of Louis XIV. The publishing industry did not reach a "takeoff" point until the development of the steam press, cheap techniques of manufacturing paper, and mass education in the nineteenth century. Increased literacy did not liberate the philosophes any more than the philosophes revolutionized society.

Actually, Gay backs away from some of his statements about literacy and revolutionizing by the end of the book. Thus the new phenomenon of mass literacy, which he announces at the beginning, declines as the dialectic unfolds, until in the end, "the overpowering presence of the illiterate masses" (2: 492) saps the philosophes' revolutionary ardor. Driven by "a sense of de-

places this "revolution" well before the Enlightenment. Of the books he examined, 62 percent were published in Latin in 1500-1509, 29 percent in 1590-1599, 7 percent in 1690-1699, and 5 percent in 1790-91 (p. 18).

19 See Fleury and Valmary. 
spair at the general wretchedness, illiteracy, and brutishness of the poor" ( 2 : 517 ), the philosophes begin to mutter about canaille, to flirt with enlightened absolutism, and to entertain ideas of a repressive, obscurantist "social religion" (2: 522). All's well that ends well. Saved from error by inconsistency, we are left in an eighteenth century we can recognize.

Gay's Enlightenment remains recognizable, despite the confusion of its dialectic, because it covers familiar territory with a refreshing sense of rediscovery. Instead of striking for the frontier, Gay set out to clear a path through the monographs cluttering eighteenth-century historiography, and he succeeded where his dialectic failed. Following him is like touring with a Guide Michelin: one stops for the occasional dégustation but never wanders far from the three-star routes. In the end, the verdict is clear: Gay's Enlightenment "vaut le voyage." But it is most valuable as one man's summing up, a synthesis of years of thoughtful reading, which one instinctively places on the shelf next to R. R. Palmer's The Age of the Democratic Revolution. Taken as a synthesis of social history and the history of ideas, however, it does not hold up because it will not stand without its dialectical scaffolding.

\section{II}

It may be misleading to compare Gay's polished synthesis with the monographic articles published in Livre et société. But the two works share a concern for what the Livre et société group sometimes refers to as "l'histoire sociale des idées," and the comparison is revealing because the French begin by resisting the urge to synthesize. In a way, they locate the Enlightenment by not looking for it: instead, they put aside preconceptions about the "philosophie des lumières" and seek out the unenlightened, the everyday, and the average. Their purpose is to reconstruct literary culture as it actually was. They therefore emphasize intellectual "inertia" and try to measure the depth of tradition, adopting an approach that had lain fallow since Daniel Mornet first experimented with it a half-century earlier.

While Cassirer was exploring the phenomenology of the Enlightenment mind, Mornet studied the Enlightenment as a social process. And while other literary scholars pondered the eighteenth century's great books, Mornet examined the means by which ideas diffused downward in society. His examination revealed that some books, which later ages took to be great, may not have been widely read under the Old Regime, ${ }^{20}$ and this revelation raised a new set of questions: What did eighteenth-century Frenchmen read? And what was the balance of tradition and innovation in early modern book culture? Mornet left these questions to his descendants in the VI ${ }^{\mathrm{e}}$ Section of the Ecole Pratique des Hautes Etudes, and especially to the research team that produced Livre et société. The researchers also inherited the techniques and traditions of the "Annales" school, which inclined them toward the study of "mentalités" rather than formal philosophic ideas and which made them receptive to the quantitative methods that Mornet had developed.

Owing to the complexity of the Old Regime and the diversity of its culture, the Livre et sociéte group tried to relate the literary and social life of eighteenth-century France by studying specific milieux: the obscure masses who "read" or listened to popular literature, the educated provincials who pur-

20 Daniel Mornet, "Les enseignements des bibliothèques privées (1750-1780)," Rev'ue d'histoire littéraire de la France 17 (1910): 449-92. 
chased traditional works, the elite of the provincial academies, and the $\mathrm{Pa}$ risians who produced and consumed certain "advanced" periodicals.

The work done on the first of these four groups makes the most exciting reading, because it gives one a sense of contact with the remote mental universe of the eighteenth-century village. Robert Mandrou showed that such contact was possible in De la culture populaire aux $17^{e}$ et $18^{e}$ siècles (Paris, 1964), a brief but brilliant study of the crude paperbacks known as the Bibliothèque bleue, which colporters hawked through the countryside, along with thread and cutlery, from the seventeenth to the nineteenth century. Printed on cheap paper with wornout type, sold for a sou, and read until they fell apart, these little books contain clues to a popular culture that is otherwise more inaccessible than the civilization inscribed on Cleopatra's Needle. They were read aloud by the few villagers who could read during the veillée, an informal evening get-together where women sewed and men repaired tools. The Bibliothèque bleue certainly belonged to a humble level of culture. Its stories often begin, "As you are about to hear. . ." But what message was communicated by this oral-written genre, and how did these books relate to the culture of the upper strata? Mandrou placed them far behind and below the Enlightenment. He showed that while the philosophes were stressing the rationality and sensibilité of human nature, the Bibliothèque bleue presented man as a slave of passion, driven by astrological forces and weird mixtures of the four humors and the four elements. While the freethinkers were naturalizing religion, the Bibliothèque bleue purveyed spiritualism, miracles, and hagiography. And while the scientists were emptying the universe of mystery, the Bibliothèque bleue filled the heads of its reader-listeners with visions of threatening, occult forces, which could be appeased by mumbo-jumbo and deciphered with recipe-knowledge-magic numbers, physiognomy, and primitive rituals. As literature, the Bibliothèque bleue adapted and simplified the medieval tales and Gaulois humor that polite society rejected in the seventeenth century. So Mandrou concluded that in comparison with the culture of the elite, the popular culture represented by the Bibliothèque bleue was both distinct and derivative. He went on to hypothesize that the popular literature of the Old Regime served as an ideological substitute for class consciousness among the masses. The peasants let their thoughts wander through a wonderland inhabited by Robert le diable, Oger le danois, Pierre de Provence, the giant Fierabras, and all manner of magical forces, instead of taking the measure of the real world of toil and exploitation.

Mandrou's study, a product of the "Annales" school but not of the Livre et société group, prepared the way for the work of Geneviève Bollème, who produced a general survey of the Bibliothèque bleue for volume 1 of Livre et société and a detailed study of popular almanacs, which grew too big for volume 2 and was published as a separate monograph. Bollème's analysis confirmed the main lines of Mandrou's but emphasized change rather than continuity in the evolution of popular literature. She found that the escapism and supernaturalism of the seventeenth century receded in the eighteenth with the influx of new attitudes: a more worldly and realistic orientation toward death, human nature, social relations, and natural forces. The old astrology and mythical tales gave way to a new sense of science and history. A new "morale sociale," an "esprit critique,"'-1 and an awareness of current

21 Geneviève Bollème, Les almanachs populaires aux XVII' 't XVIII' siècle's: Essai d'histoire sociale (Paris, 1969), p. 84. 


\section{Robert Darnton}

events indicated the penetration not merely of the Enlightenment but also of incipient revolutionary ideas. ${ }^{2-2}$ Despite their similarities, therefore, the studies of Mandrou and Bollème point in opposite directions, the first toward the separation of cultural worlds and the intellectual enserfment of the masses, the second toward an increase in cultural integration, with popular literature acting as a liberating force.

It is too early to tell which view will prevail because there has not yet been enough detailed study of the many genres of popular literature. Bollème's work is more detailed, as it concentrates on one genre - the popular almanac - whose development can be traced with some precision through the seventeenth and eighteenth centuries. But the attempt to be precise about the cosmology of the common man raises methodological problems that did not hamper Mandrou's more general and impressionistic work. For not only did Bollème move beyond general impressions, she attempted to enter right into the minds of the almanacs' reader-listeners, and there she found not merely mumbo-jumbo but "Kantian":-3:3 categories. The categories-“observations astrales perpétuelles,"'-4 for example-do not summon up the Critique of Pure Reason. Instead, they arouse skepticism: Do the almanacs reveal the workings of the popular mind, or is this upside-down Cassirer? Bollème did not prove the "popular" character of her almanacs. On the contrary, she drew material from some almanacs in bindings with aristocratic coats of arms; from others that expressed scorn for "les préjugés populaires";25 and from several that did not aim their aphorisms at the illiterate or the indigent: "Lis souvent"; "Achète des livres en tout temps"; "Ne tyrannisez point le pauvre débiteur"; "Peragit tranquilla potestas quod violenta requit."'26 Poor Richard (a favorite in France) belonged in part to the lost, aristocratic world of Thomas Jefferson. There were almanacs for everyone, even in the upper reaches of the Old Regime. Bollème acknowledged the differences among the almanacs but she grouped them all together for the purpose of analysis. And when she analyzed changes in the world view of the eighteenth-century populace she based her conclusions almost entirely on a sampling of only twenty-seven undifferentiated almanacs. The almanac upon which she relied most heavily and which she cited most often as evidence of advanced opinion at the popular level was Le messager boiteux, a work printed in Bern, Bâle, Yverdon, Vevey, and Neuchâtel-that is, by Swiss and in some instances by Protestants: not a reliable index to the attitudes of Catholic French peasants. ${ }^{27}$

But how reliable are the most folksy and most French of the almanacs? Frequently presented as the aphorisms of one shepherd ("le Grand Berger de la Montagne") addressing others, they have more of the flavor of Renaissance pastoralism than of a genuine shepherd-to-shepherd dialogue. The pastoralism may have been adapted for mass consumption from the "model"

2 See esp. ibid., pp. 123-24, 16, and 55.

$2: 3$ Ibid., p. 95.

26 Ibid. (in order of citation) pp. 74, 79, 75, and 81 .

27 The versions published in Yverdon and Vevey by Jeanne-Esther Bondeli and Paul-Abraham Chenebié derived from the Hinckende Bote of Bern, a German almanac produced by Emmanuel Hortin, the son of a Protestant minister (see Jules Capré, Histoire du véritable messager boiteux de Berne et Vevey [Vevey, 1884] and Jeanne-Pierre Perret, Les imprimeries d'Yverdon au XVII et au XVIII' siècle [Lausanne, 1945], pp. 74-78). 
almanac of the fifteenth century, Le grand compost des bergers, but the rhetorical pose might have had more in common with the masquerading of Marie-Antoinette than the mountainside egalitarianism detected by Bollème. The almanacs represent a popularization of upper-class culture, not popular culture in itself, because they were written for the people, not by the people, and they were not so much "written" as adapted in the most casual fashion, sometimes even by typesetters, from the literature of the elite. The great problem is not to extract their message, but to know whether that message was integrated in the indigenous culture of the masses.

Mandrou believed it was. The real dialogue, in his view, did not involve shepherds but publishers and colporters. The wandering salesmen knew what the peasants would buy and stocked up accordingly, thereby determining, in the long run, what the publishers produced. This argument seems convincing, but it applies more aptly to upper-class literature, which was far more sensitive to changes in styles and ideas than was the extremely standardized repertory of the Bibliothèque bleue. Unlike the educated elite, villagers may have been passive consumers of literature; they may have bought whatever was available, just because they wanted something-it hardly mattered what - to submit to the veillée reader or to stare at themselves. As Bollème put it, there could have been an element of "magic," 2. a mystical respect for the word, in primitive reading-an obscure psychological process that probably had little relation to the sophisticated reading and consumer control that went on in high society. So changes in popular literature could have been imposed from above without being assimilated at the village level. The actual culture(s) of France's heterogeneous masses remains lost in an unfathomable ocean of oral tradition; the books that dropped into it probably disappeared without much effect, like missionaries in India.

Although the work of Mandrou and Bollème may have failed to define the popular culture of eighteenth-century France, it enormously enriches the conventional view of the "Age of Reason." By revealing the existence and character of a vast literature that circulated on levels far below the philosophes, it helps place the Enlightenment in perspective. This attempt to define levels of cultural experience and to relate reading to specific social sectors is also the strong point of the other essays in Livre et société, especially the study of provincial reading by Julien Brancolini and Marie-Thérèse Bouyssy. After examining book consumption in the provinces by genre and by region, Brancolini and Bouyssy concluded that educated provincials were about as far removed from the Enlightenment as illiterate peasants. The weight of traditional culture crushed innovation in town and village alike.

The Brancolini-Bouyssy study was based on a quantitative analysis of the records of requests by provincial publishers for permissions simples, a kind of authorization to produce works that had fallen into the public domain by virtue of legislation reforming the book trade in 1777 . These requests included the projected number of copies for each edition, so they provide more precise information than any of the sources consulted in previous attempts to chart the boundaries of literary culture in the Old Regime. The most important of these attempts was published by François Furet in volume 1 of Livre et société. It indicated that an enormous quantity of religious works and pre-eighteenth-century "classics" all but smothered the Enlightenment,

28 Bollème, pp. 15-16. 
although the production of scientific books and secular fiction increased at the expense of religious literature as the century progressed. Furet's findings derived from quantitative analysis of requests for privileges (strictly legal authorizations to publish) and permissions taçites (more flexible and less formally legal authorizations). But they lacked data on the size of editions and the places where the books were marketed. Brancolini and Bouyssy provided precisely that information, thereby supplementing and confirming Furet's analysis. Taken together, the two studies suggest that cultural "inertia" weighed heavily on all of France and that the inroads of "innovation" did not penetrate far beyond Paris. Not a surprising pattern-unless it is measured against the conclusions of Geneviève Bollème. For she saw modernization galloping full tilt through the crude almanacs of the late eighteenth century, while Brancolini and Bouyssy found nothing but cultural stagnation at a more sophisticated level of literature. Did the literary experience of the elite and of the masses somehow converge without meeting on the middle ground of the middle classes?

This paradox, like so many of the problems in quantitative history, may arise from insufficiencies in the data. Requests for permissions simples do not represent the "vie provinciale du livre," as Brancolini and Bouyssy claim, because the permissions simples excluded probably the most important component in the stock of provincial bookdealers: books acquired by purchases or, more often, by exchanges measured in page gatherings with publishers located in other regions or other countries. The permissions simples also excluded all books published in France under permissions taçites, the legal loophole through which much of the Enlightenment reached French readers.? In fact, the permissions simples covered primarily a specialized and unrepresentative segment of the provincial book trade: the relatively stable market for schoolbooks and religious works. With the expiration of old privileges, the provincial publishers supplied new editions of old books to local teachers, priests, and teacher-priests. But they might have supplied other readers with an equal number of "advanced" works, which could not have appeared in the Brancolini-Bouyssy data.

Although the data fail to prove the backwardness of provincial culture, they do provide a very revealing picture of regional variations in French reading. They show that book production corresponded with the incidence of literacy as measured by the Maggiolo study mentioned above. The great majority of permission-simple books circulated north of the Maggiolo line. Moreover, the north's areas of highest literacy and highest book production, like Lorraine and Normandy, were areas where the Counter Reformation had been most effective and where nineteenth- and twentieth-century voters showed most attachment to the church. Northern readers tended to favor the religious "classics" of the seventeenth century and even Jansenist works, while southerners, especially around Toulouse, read a relatively high proportion of secular literature. A series of maps illustrates the point in rich detail. So despite the limitations imposed by its data, the Brancolini-Bouyssy study suggests some of the complexities and the long-term trends in the cultural history of France.

29 For details on the permissions simples, see the text of the edict of August 30, 1777 in Jourdan, Decrusy, and Isambert, eds., Recucil général des anciennes lois françaises (Paris, 1826), 25: 108-12. 
Daniel Roche's monographs on provincial academies, published in volumes 1 and 2 of Livre et sociéte, analyze the character of the intellectual elite in the areas where Brancolini and Bouyssy tried to provide an overall measurement of literary culture. Like all elite studies, Roche's investigation compensates in specificity for what it lacks in generality; but here the specifics of quantitative analysis have important general implications, for they define some of the milieux through which the diffusion of "lumières" was refracted. Taking a cue from Mornet, who had stressed the importance of studying the provincial academies in Les origines intellectuelles de la Révolution française, Roche began with an analysis of the academies' social composition. By adopting a carefully nuanced classification scheme, he reduced such abstract problems as the supposedly "bourgeois" character of the Enlightenment to manageable proportions. He found that the membership of the academies of Bordeaux, Dijon, and Châlons-sur-Marne corresponded to the hierarchies of provincial society. The landed aristocracy, service nobility, and (especially in the parlementary towns) the nobles of the robe dominated the academies, which themselves were privileged corporations in a society characterized by privilege and corporateness. The academies' lower ranks (correspondants and associés) become increasingly bourgeois as the century progressed-but not bourgeois in the Marxist sense. The lesser academicians were civil servants and professional men, including a very high proportion of doctors and virtually no financiers, industrialists, or merchants, even in the booming commercial center of Bordeaux. Thus the academies represented a traditional elite of notables, opening up increasingly to men of talent but not to capitalist entrepreneurs. They were also open to new ideas. The topics set for their prize essay contests show concerns related to the Enlightenment: humanitarianism, a tendency to move from abstract to utilitarian thought, and an increasing interest in political economy. The men who gave first prize to Rousseau's Discours sur les sciences et les arts had a very unrousseauistic faith in the parallel advancement of science and social welfare.

In his second article, Roche produced a comparative social analysis of the academicians and the collaborators of the Encyclopédie identified by Jacques Proust in Diderot et l'Encyclopédie. Like the academicians, the encyclopedists contained a large number of professional men (especially the omnipresent enlightened doctors), savants, and technicians supplemented by a heavy dose of nobles and civil servants (20 percent in each case) but not a single merchant. So the Encyclopédie itself seems to have represented a tendency of old elites to assume a new role of intellectual leadership in conjunction with the nascent "bourgeoisie de talents" rather than the industrial-commercial bourgeoisie. That conclusion should be handled with care, however, because it rests on a fragile statistical base of 125 encyclopedists whose social and professional status could be identified. Since Diderot had more than 200 collaborators, Proust and Roche may not have worked with representative statistics. The statistics were too small, in any case, to represent large social groups. Because the encyclopedists included only nine abbés, eight parlementaires, and seven lawyers, it does not follow that those three groups were more immune to encyclopédisme than doctors, who contributed twenty-two collaborators. A dozen men in any category could change the statistical picture completely. As Proust pointed out, it was a community of intellectual interest, not a common social milieu, that bound together the collaborators of the 
Encyclopédie. They did not cast off the old deference patterns: in fact Proust found a kind of deferential differential in Diderot's correspondence, which shows Diderot talking down to social inferiors, like Rousseau, while chatting up more established writers, like Voltaire, Buffon, and Marmontel. ${ }^{30}$ Nonetheless, a common intellectual cause united the men at the center of the Enlightenment. When their message spread outward, it had to pass downward, through the traditional hierarchies of provincial society. This was the enlightening process as d'Alembert and Voltaire conceived it-a slow seeping of lumierre from the top to the bottom of the social pyramid, without any leveling or lowering effects. Thus the studies of Proust and Roche complement each other nicely, showing the traditional society's ability to absorb new ideas and the traditional elite's capacity for acquiring new functions-but not a new ideology rising with a new economic class. The social history of ideas seems to have broken out of the old categories of Marxist sociology. ${ }^{31}$

Most of the articles in Livre et société emphasize continuity rather than change. By macroanalysis of book production and by concentrating on peasants and provincials, they, reveal the weight of tradition in the cultural lives of the great majority of Frenchmen. One study, however, by Jean-Louis and Marie Flandrin, concerns the milieu at the center of cultural innovation, the salon society of Paris. Here, as in Proust's work on the encyclopedists, quantitative history came into direct contact with the Enlightenment. The Flandrins tried to measure the literary experience of the Parisian elite by tabulating references to books in three journals: the Journal of Joseph d'Hémery, the police inspector for the book trade; the Mémoires secrets of Bachaumont; and the Correspondance littéraire of Grimm. Each of the three was written for private consumption and therefore contained material on avant-garde works that could not be reviewed in standard periodicals like the scrupulously censored Journal des savants. A statistical analysis of reviews in the Journal des savants and in the Jesuit Mémoires de Trévoux which was published in volume 1 of Livre et société, had revealed a "traditional" bias almost as pronounced as in the Furet and Brancolini-Bouyssy studies. ${ }^{32}$ But the Parisians who read and sometimes even edited these censored periodicals came from the same literary circles that the Flandrins studied; and in analyzing the clandestine press the Flandrins found unalloyed Enlightenment. Seen through the Journal des savants, the Parisians look like Brancolini's provincials; they kept to a sparse diet of old-fashioned devotional, historical, and legal works, seasoned with some science. Seen through the Mémoires secrets, the Parisians glutted themselves on philosophy, read very little history, and no religious, legal, or purely scientific books. Wherever the distortion may be, it results from the selection of data, not from statistical imprecision. The Flandrins' statistics seem impeccable, but the journals that provided them did not mention all the books read in salon society. They referred only to the extraordinary, controversial books, the books that were talked about and that made

30 Proust, chap. 1.

31 Robert Mandrou's interpretation of Proust's research seems distorted, at least to this reader (see Mandrou, La France aux XVII' et XVIII" siecles, pp. 168-69: "le XVIII" siècle pense vraiment bourgeois").

32 Jean Ehrard and Jacques Roger, "Deux périodiques français du 18" siècle: 'le Journal des savants' et 'les Mémoires de Trévoux.' Essai d'une étude quantitative," in Livre et société, vol. 1. 
news. These journals were really primitive newspapers-nouvelles à la main -not systematic literary reviews. They provide information about literary vogues but no quantifiable index to book consumption that can be compared with the statistics of Furet and Brancolini. So the "circulation du livre" in Paris and the cultural distance between Parisian innovators and provincial followers has yet to be measured.

The remainder of Livre et société constitutes an attempt at measuring an even more elusive phenomenon: language. Historical semantics is now a booming discipline in France and one that promises to enrich the standard views of the Enlightenment by uncovering implicit concepts, the kind that escape exegeses of formal thought. ${ }^{33}$ Unlike conventional lexicology, historical semantics does not treat words as isolated units but rather as parts of a semantic field, a linguistic structure in which each part conveys meaning through its function within the whole. To grasp the meaning of individual eighteenth-century words, it therefore is necessary to reconstruct the linguistic structure of eighteenth-century French, treating the language as a fluid, socially determined system of communication, not as a fixed crystallization of thought from which parts can be arbitrarily detached. Put abstractly, these propositions seem reasonable enough; the difficulty is to put them into practice by discovering the mental processes behind eighteenth-century French as it has come down to us in the form of words congealed on paper. The research for volume 1 of Livre et société produced a special collection of specimens of this dead communications system-a list of 40,000 book titles registered for privileges and permissions taçites. By analyzing each title as a semantic field, computing the results statistically, and organizing the statistics into a series of semantic models, François Furet and Alessandro Fontana tried to get at the meaning of two eighteenth-century words, histoire and méthode.

Fontana's study, the more elaborate and ambitious of the two, best represents this new historical discipline. After 100 pages of laborious analysis, Fontana produced a "structural profile" of eighteenth-century méthode. In some cases, he concluded, méthode was fixed, final, and transcendental or mathematical; in others it was fragmented, variable, and relative to particular disciplines. Its varied usage revealed a thought pattern moving from seventeenth-century apriorism to nineteenth-century relativism, and so suggests a cosmological shift that might be compared with the transition from the closed to the infinite universe that Alexandre Koyré discerned in studying the history of science.

Whether or not Fontana proved his case is difficult to say, owing to the linguistic barriers to understanding linguistics. No uninitiated reader should confront Fontana's monograph unless armed with something much more formidable than a Petit Larousse, for he will get trapped in an impenetrable semantic underbrush. He may pride himself on having mastered the mots-clés of the "Annales" school: conjoncture, contingence, synchronie-diachronie, and mot-clé. But what is he to make of mathésis, apax, inessif, hendiadys, ethnosème, and semiosis? At the risk of seeming ubusif, anti-sememic, or an

33 For reports on the state of historical semantics, see Actes du $89^{\circ}$ congrès des sociétés savantes (Paris, 1964), vol. 1; and M. Tournier et al., "Le vocabulaire de la Révolution: pour un inventaire systématique des textes," Annales historiques de la Révolution française, no. 195 (January-March 1969), pp. 109-24. 
outright idiolect, this reviewer must confess that he cannot follow Fontana's argument and that he finds historical semantics more impressive in principle than in practice.

But the two volumes of Livre et société do represent an impressive attempt to rescue the intellectual history of eighteenth-century France from vague generalizations and to root it in the realities of social history. They reveal the general contours of literary culture as it was experienced by the great mass of eighteenth-century Frenchmen rather than as it appears in a few, posthumously selected classics. And they relate that literary experience to specific social groups - the obscure millions who participated in popular culture, the more elevated reading public of the provinces, the provincial elite, and the Parisian avant-garde. Whatever their shortcomings, these experimental essays show that the social history of ideas can be written. They do not redefine the Enlightenment any more successfully than Gay does, but they help to situate it in the complex context of eighteenth-century society.

\section{III}

The comparison of Gay's Enlightenment and Livre et société suggests that the social history of ideas must move out of its armchair phase and into the archives, tapping new sources and developing new methods. For how can it be written from within the confines of even a first-rate library? To pull some Voltaire from the shelf is not to come into contact with a representative slice of intellectual life from the eighteenth century, because, as the Livre et société essays show, the literary culture of the Old Regime cannot be conceived exclusively in terms of its great books. Yet libraries crammed with classics cannot find room for the Bibliothèque bleue, a genre too undignified to be classified with "books" or to fit into our preconceptions about "culture." And every year our universities turn out thousands of certified experts in Western civilization who have read the Social Contract many times and have never heard of Les quatre fils Aymon. As far as the social history of ideas is concerned, the difficulty is not simply in recognizing "low" as well as "high" culture, because Gay's techniques - a matter of index cards and intelligence, but no original research-will not even uncover the social history of the intellectual elite. The finances, milieux, and readership of the philosophes can only be known by grubbing in archives.

If read as conventional intellectual history, however, Gay's Enlightenment has the great advantage of imposing new form on a great deal of unmanageable old matter. Livre et société holds out little hope for arriving as such a heroic synthesis. Instead, it suggests that we must face another outbreak of monographs, which will take us in a dozen different directions, wherever the data lead. As the data tend to be statistical, they continually raise problems about quantifying cultural phenomena. Literary journals cannot be reduced meaningfully to bar graphs, and literary "influence" still seems too intangible to be computerized. Statistics about book consumption give one a general sense of the cultural terrain, but do not explain the meaning of what it is to "consume" a book. So the social history of ideas is searching for a methodology. It will probably fall back on ad hoc combinations of Cassirer and Mornet until it develops a discipline of its own. If those two masters cannot yet be brought together in a new definition of the Enlightenment, they cannot be left alone. And seen through the work of their successors, their achievement looms larger than ever. 